\title{
"THE EFFECT OF RICE SOWING ON THE SEEDLING METHOD FOR DIFFERENT PERIODS, PLANTING PATTERN AND THE NUMBER OF SEEDLINGS"
}

\section{Tursunov Hayrullo Odiljonovich,}

$\mathrm{PhD}$, Andijan branch of Tashkent state agrarian university

Juraeva Hurmatoy Rafikjonovna,

$\mathrm{PhD}$, Andijan branch of Tashkent state agrarian university

Juraev Akmaljon Normuhamadovich,

$\mathrm{PhD}$, Andijan branch of Tashkent state agrarian university

\section{ABSTRACT:}

The article provides information on the effect of the optimal amount of seedlings, planting patterns and timing on plant growth cycles when growing rice as a secondary crop. Nowadays, the demand for food is also increasing tremendously as a result of the rapid growth of the world's population. This indicates that the issue of food security will become more complicated in the future. Like all food products, the population's demand for rice is growing from year to year. According to official FAO data, by 2020 , the total volume of rice production should reach 750 million tons to meet the demand of the world population for rice.

Keywords:

seedling method, rice, secondary crop, the number of seedlings, planting pattern, sowing period, growth period, yield.

Article Received: 18 October 2020, Revised: 3 November 2020, Accepted: 24 December 2020

\section{INTRODUCTION}

Today it is important to increase cereal crops, including rice, to meet the food needs of the world's population. Worldwide, rice was grown on 155 million hectares in 2018, nearly 95 percent of which was planted as seedlings. In terms of sown area, India ranks first (43.4 million/ha), second China (30.8 million/ha), third - Indonesia (13.8 million/ha) and fourth place Bangladesh (11.8 million/ha) ) Thailand occupies the fifth place (10.8 million/ha), and Vietnam occupies the sixth place (7.8 million/ha)."

In recent years, world agriculture has been conducting intensive research on the application of new innovative resource-saving technologies on a scientific basis to increase the yield of rice harvested two or three times a year. In this regard, it is important to improve the existing technologies for the cultivation of environmentally friendly, abundant and highquality products from rice, to pay special attention to a clear agricultural management system (1. 4-10 p). Efficient use of vacant lands of autumn cereals and other early crops, rational timing of planting of seedlings of rice varieties, determination of the scheme and number of seedlings, optimization of agro-technical elements are important theoretical and practical tasks.

\section{MAIN PART}

Agricultural activities on the experimental field were carried out on the basis of the "Recommendations on the technology of rice cultivation in the conditions of Uzbekistan" (2010) of the Rice Research Institute.

The study identified phenological observations for determining biometric parameters in all returns and field experiment options using "Methods of conducting field experiments" (3. 8$51 \mathrm{p}$ ), agrophysical and agrochemical analysis of the soil according to "Methods of agrochemical study of soil and plants of Central Asia" (2. 350$423 \mathrm{p}$ ), , calculation of the level of rice plant leaves Vishnu M. Bhan and HK Pande (IRRI), calculation of the sum of useful temperatures was determined by the method of Qunying Luo, Michael Bange and Loretta Clancy.

The experiments were carried out 12 options in 4 repetitions each option 100 sq.m. 
and a total of 4800 sq. area, 5190 sq. m. (Table

1),

4. Ochilov E., Kashkarov N. Fundamentals of scientific research in bot

\section{Applications}

Table 1

\section{Experimental system}

\begin{tabular}{|c|c|c|c|}
\hline $\begin{array}{l}\text { Experiment } \\
\text { options }\end{array}$ & $\begin{array}{c}\text { Timing of } \\
\text { planting seedlings }\end{array}$ & Planting scheme & $\begin{array}{l}\text { Number of seedlings } \\
\text { per thousand / ha }\end{array}$ \\
\hline \multicolumn{4}{|c|}{ Guljahon } \\
\hline Option 1 & \multirow{3}{*}{ June 25} & $30 \times 10 \times 1$ & 333 \\
\hline Option 2 & & $30 \times 10 \times 2$ & 666 \\
\hline Option 3 & & $30 \times 10 \times 3$ & 999 \\
\hline \multicolumn{4}{|c|}{ Iskandar } \\
\hline Option 4 & \multirow{3}{*}{ June 25} & $30 \times 10 \times 1$ & 333 \\
\hline Option 6 & & $30 \times 10 \times 2$ & 666 \\
\hline Option 5 & & $30 \times 10 \times 3$ & 999 \\
\hline Option 7 & \multirow{3}{*}{ July 5} & $30 \times 10 \times 1$ & 333 \\
\hline Option 8 & & $30 \times 10 \times 2$ & 666 \\
\hline Option 9 & & $30 \times 10 \times 3$ & 999 \\
\hline Option 10 & \multirow{3}{*}{ July 15} & $30 \times 10 \times 1$ & 333 \\
\hline Option 11 & & $30 \times 10 \times 2$ & 666 \\
\hline Option 12 & & $30 \times 10 \times 3$ & 999 \\
\hline
\end{tabular}

Table 2

Agrochemical analysis of soil before sowing of experimental field 2017-2019 yy

\begin{tabular}{|c|c|c|c|c|c|c|c|c|}
\hline № & \multirow{2}{*}{$\begin{array}{c}\text { Soil } \\
\text { layer, } \\
\mathbf{c m}\end{array}$} & \multirow{2}{*}{$\begin{array}{c}\text { Humus, } \\
\mathbf{\%}\end{array}$} & \multicolumn{3}{|c|}{ The total amount of nutrients, \% } & \multicolumn{3}{|c|}{$\begin{array}{c}\text { Moving amount of } \\
\text { nutrients. \% }\end{array}$} \\
\cline { 4 - 9 } & & nitrogen & phosphorus & potassium & $\begin{array}{c}\mathbf{N}- \\
\mathbf{N O}_{3}\end{array}$ & $\mathbf{P}_{\mathbf{2}} \mathbf{O}_{\mathbf{5}}$ & $\mathbf{K}_{\mathbf{2}} \mathbf{O}$ \\
\hline $\mathbf{1}$ & $0-30$ & 1,85 & 0,171 & 0,146 & 1,63 & 21,4 & 31,4 & 205 \\
\hline
\end{tabular}

The seedlings were planted by hand and

including a common security zone and corridors (4. 3-8 p) the experimental lands were prepared on the basis of the recommended technology, so that the field was covered with water in a layer of $1-3 \mathrm{~cm}$ before planting.

Feeding, the compliance with water standards, which is one of the main factors in caring for rice plants, was carried out in 
accordance with the agricultural technology developed by the Rice Research Institute in 2010, and the initial recommendations for the varieties "Guljahon" and "Iskandar".

During rice care, at the first feeding at the beginning of the tillering period, $50 \%$ of the annual amount per hectare was introduced, i.e. 90 $\mathrm{kg}$ of nitrogen, $60 \mathrm{~kg}$ of phosphorus and $60 \mathrm{~kg}$ of potassium per hectare in pure form, and for the second feeding $90 \mathrm{~kg}$ of nitrogen, $60 \mathrm{~kg}$ of phosphorus and $60 \mathrm{~kg}$ of potash fertilizer per hectare during tillering (5. 42-84 p). Feeding, irrigation and all other rice cultivation measures were carried out in the same agro-fund in all options.

\section{DISCUSSIONS}

When agrochemical analysis of soil samples was used the manual "Methods of agrochemical, agrophysical and microbiological research in irrigated areas". The analysis of the agrochemical state of the soil was carried out at the beginning and at the end of the rice growing period in each $10-\mathrm{cm}$ layer $0-30 \mathrm{~cm}$ deep from each option, and it was analyzed humus in the soil (according to the Tyurin method), total nitrogen, total phosphorus (according to the method of Maltsev, Gritsenko), nutrients in mobile form in the soil, nitric acid nitrogen (according to the Granwald-Liai colorimetric method), mobile phosphorus (according to the Machigin method), exchange potassium (according to the Protasov method).

Analyzes show that it is not difficult to see that the amount of humus in the soil has decreased significantly below the driving layer. It was found that $1.85 \%$ at

$0-30 \mathrm{~cm}$ in the driving layer and at $30-50$ $\mathrm{cm}$ its content was $1.01 \%$ relative to the weight of the soil (Table 2).

When special nurseries are ready for sowing, 40-50 kg of nitrogen $40-50 \mathrm{~kg}$ of phosphorus and $50 \mathrm{~kg}$ of potash mineral fertilizers per hectare are added to the soil in pure form and mix well. The preparation of rice seedlings in special nurseries began in the second half of May for planting rice as a secondary crop. In this case, the method of sorting the seeds prepared for sowing in salt water was used. This method is based on the principle that fully immature or thin-shelled grains float to the surface due to the increase in water density. To do this, 301 of water was poured into a container with a capacity of 401 , into which salt was slowly added and mixed. Mixing with salt was continued until a raw bird (chicken) egg in solution floated to the surface of the water without drowning. Once the egg had fully floated to the surface of the water, the salting was stopped and the rice seeds prepared for sprinkling in the saline solution were added and mixed slowly. As a result, part of the rice seeds, i.e., the immature and empty grains, floated to the surface of the solution, and the remaining part of the whole grains sank to the bottom of the solution. The empty grains that floated to the surface of the solution were removed to the waste. Whole grains settled to the bottom of the solution were taken in a separate container and washed twice in clean water (6. 20$21 \mathrm{p})$. The seedlings were transplanted to the main field when they were 30 days old, ie 30 days in the early Guljahon variety and 30 days in the middle Iskandar variety. 4-5 days before transplanting, the seedlings received $50 \mathrm{~kg}$ of pure nitrogen fertilizer (ammonium nitrate) per hectare, because in other experiments after that the rice seedlings became stronger and settled faster in the new soil.

When using the seedling method, the soil and climatic conditions of the rice field are of great importance. When studying the timing of planting seedlings in tropical countries, the highest yields were obtained when planted in June-July at 85-96 c/ha (10. 129-137 p). When the influence of planting time on rice development periods was studied, it was found that the lowest indicator of the development period before flowering was recorded during planting in January and March for all varieties (77 days of earlyripening and 127 days of late-ripening varieties), and the highest indicator was recorded when planting in November(117 days of early-ripening 
and 152 days of late-ripening varieties). V.Veiraraj Urs., M. Mahadevoppen, M. Ahuthan Nayar, C. M. George (1974) noted that some biological properties of rice and its yield depend on the time of year and solar radiation.

When studying the influence of different planting patterns and the timing of rice cultivation as a secondary crop in Andijan region to study the effect on plant growth, the seeds of two rice varieties, the early ripening variety "Guljakon" and the mid-ripening variety "Iskandar" were soaked in water and sown in three different periods (May 25 June 5 and June 15).

Before sowing the seeds of rice varieties in the nursery, the level of germination was studied in two different environments in the laboratory, ie in the aquatic and soil environment, as well as in field conditions. In the second decade of May, when the average daily temperature was $20.6{ }^{\circ} \mathrm{C}$, the germination rate of Guljahon seeds was $96.2 \%$ in aqueous environment, $50.9 \%$ in laboratory conditions and $45.2 \%$ in field conditions. The germination rate of Iskandar seeds was $96.3 \%$ in aquatic environment, $51.5 \%$ in laboratory conditions and $49.7 \%$ in field conditions.

In the third decade of May, it was found that the seeds of Guljahon and Iskandar varieties of rice sown on May 25 fully germinated on June $1-2$, ie 7-8 days after sowing. In the first decade of July, rice seeds sown on July 5 germinated on the 9th of this month, ie 4 days after sowing. In the second decade of July, rice seeds sown on July 15 were found to have fully germinated on July 19 and formed grasses. It can be seen that rice seeds sown in the first and second decades of June germinated 3-4 days earlier than rice seeds sown in the third decade of May.

In accordance with the biology of the rice variety in the nursery, the period of tillering began 21-24 days after sowing. When the plants that started the tillering period turned 30 days old, from the nursery to the experimental zone in three different planting periods, June 25, July 5 and July 15 , twelve options were planted in three different planting patterns: 30x10x1 333 thousand pcs/ha, 30x10x2 666 thousand pcs/ha, 30x10x3 999 thousand $\mathrm{pcs} / \mathrm{ha}$, and the following results were obtained in the experimental field.

In the first option, when, 30-day-old seedlings of the early-ripening variety Guljahon were planted in the third decade of June according to the first option with 333 thousand pcs/ha, i.e., planted according to the $30 \times 10 \times 10$ pattern, seedlings entered the tillering period in the third decade of July 23 July, 57 days after sowing seeds, 28 days after planting seedlings. During this period, 666 thousand seeds were sown per hectare, that is, in the second option, sown according to the 30x 10x10 scheme, in the second decade of July 19 July, 54 days after sowing the seeds, 24 days after planting, the tillering period began in seedlings.

In the third option of the $30 \times 10 \times 3$ scheme, in which 999 thousand seedlings were planted per hectare of the experiment, in the second decade of July, July 15, 49 days after sowing the seeds, 20 days after planting, the seedlings entered the period of full tillering. As mentioned above, despite the fact that the same variety was planted at the same time $(06 / 25)$, it was found that in the first option, planted according to the 30x 10x1333 thousand $\mathrm{pcs} / \mathrm{ha}$ scheme, the tillering process lasted 3-6 days from the date of sowing seeds and 4-8 days from the date of sowing seedlings in comparison with the second option planted according to the scheme $30 \times 10 \times 2666$ thousand pcs/ha and the third option planted according to the scheme 30x10x3 999 thousand pcs/ha.

In the experiment, the 30-day-old seedlings of the mid-ripening Iskandar varieties in the third decade of June amounted to 333 thousand seedlings per hectare, that is, in the fourth option planted according to the $30 \times 10 \times 1$ scheme, in the third decade of July, July 26, 60 days after sowing seeds, 31 days after sowing seedlings, the tillering period began. In the fifth option of the 30x10x2 scheme, where 666,000 seedlings were planted per hectare of the experiment, in the third decade of July, July 22, 56 days after sowing the seeds, 27 days after planting the seedlings, the seedlings entered a period of complete tillering. The sixth option is a rice plant according to the scheme 30x10x3 planted 999 
thousand seedlings per hectare, in the third decade of July, July 20, 54 days after sowing seeds and 25 days after planting seedlings, seedlings fully entered the tillering period.

Despite the fact that in the mid-ripening "Iskandar" variety the same variety was planted at the same time $(06 / 25)$, it was found that in the fourth option, planted according to the 30x10x1 333 thousand $\mathrm{pcs} / \mathrm{ha}$ scheme, the tillering process lasted 4-8 days longer from the date of sowing seeds and from the date of sowing seedlings in comparison with the fifth option planted according to the scheme $30 \times 10 \times 2666$ thousand pcs/ha and the sixth option planted according to the scheme 30x10x3 999 thousand pcs/ha.

If experimental data are taken into account, the tillering period of mid-ripening Iskandar rice seedlings is the same as in the early Guljahon, that is, in the third decade of June, the scheme 30x10x10 333 thousand pcs/ha, the scheme 30x10x2 666 thousand pcs/ha, the scheme 30x10x3 999 thousand pcs/ha showed a longer duration - 4-11 days, according to the biology of the variety and planting patterns planted options.

Experience shows that when studying the length of the tillering period in the second decade of July, it amounted to 333 thousand seedlings per hectare, that is, in the tenth option, planted according to the $30 \times 10 \times 1$ scheme, there were 666 thousand seedlings per hectare. That is, in the eleventh option planted as seedlings according to the $30 \times 10 \times 2$ scheme and in the twelfth option of the 30x10x3 scheme, in which 999 thousand seedlings were planted per hectare, in the third decade of June it was noted that among the options planted according to the same schemes, days from the sowing date seeds were shorter, from 1 to 5 days, and from the date of sowing seedlings - 5-21 days shorter. This process is explained by the fact that the period of transplantation of rice plants shifts more and more on hot days, that is, the later or hot the planting, the faster the tillering begins, but the duration of the tillering period is reduced to 5-21 days.

The experiments also showed that when rice seedlings are transplanted from the nursery to the main field, the tip of the main root of the rice seedling is cut off, which leads to a certain state of injury, that is, external influences exerted by a person, that is, anthropogenic influences change growth, development and other physiological processes plants in subsequent periods of development (9. 1-4 p). When the tip of the main root is cut off, the lateral roots begin to grow rapidly, which leads to the appearance of new ones, and similar possibilities appear in the lateral stems.

As if from sleeping buds, there are many additional lateral roots and lateral stems. This biological feature of the plant has also been proven in our experience (8. 74-109 p).

At the end of the period of complete tillering, the period of stem elongation began, in both varieties of the experiment, i.e. in the early ripening "Gulzhakhon" and mid-ripening "Iskandar", the yield was 333,000 per hectare, that is, in the option with seedlings according to the $30 \times 10 \times 1$ scheme, there were 666 thousand seedlings per hectare, that is, there was no significant difference between the option planted as seedlings according to the $30 \times 10 \times 2$ scheme, and with a option of the $30 \times 10 \times 3$ scheme planted 999 thousand seedlings per hectare, it was noticed that the difference averaged almost 1-2 days. This pattern has been preserved even during the ear formation and flowering periods of the plant.

Although the difference in the ear formation and flowering periods was not great, it was very noticeable at the end of the ripening period. That is, by this time the rice plant stopped growing and entered the period of milk, wax and full ripening (7. 23-24 $\mathrm{p})$.

30-day seedlings of Guljahon variety in the third decade of June 333 thousand pcs/ha, that is, in the first option, planted according to the 30x 10x1 pattern, in the third decade of September, September 23, 87 days after planting seedlings and 117 days after sowing fully ripe. During this period, 666 thousand pcs/ ha were sown, that is, in the second option, planted according to the $30 \times 10 \times 10$ scheme, the period of full ripening 
began in the second decade of September, September 15, 81 days after planting and 111 days after sowing seeds.

In the third option of the $30 \times 10 \times 3$ scheme, in which 999 thousand seedlings were planted per hectare of the experiment, in the first ten days of September a full ripening period also began on September 9, 75 days after planting and 105 days after sowing. In this variety, as mentioned above, although the same variety was planted in the same period $(06 / 25)$, it was established in the first option that planted 333 thousand pcs/ha according to the $30 \times 10 \times 10$ scheme has a longer ripening period - 6-12 days compared with the second option, planted at 666 thousand pcs/ha according to the $30 \times 10 \times 2$ scheme, and the third option from 999 thousand $\mathrm{pcs} / \mathrm{ha}$ according to the 30x10x3 scheme.

30-day-old Iskandar seedlings were planted in the third decade of June (06.25) 333 thousand $\mathrm{pcs} / \mathrm{ha}$, i.e. in the fourth option, planted according to the 30x10x1 pattern, in the third decade of September, September 28, 94 days after planting the seedlings and 124 days after sowing the seeds, the period of full ripening began. Over the same period, the number of seedlings per hectare amounted to 666 thousand pcs/ha, i.e. according to the fifth option, planted according to the 30x10x10 scheme, in the third decade of September, September 24th, 88 days after planting, 118 days after sowing, the period of full ripening began. In the sixth option of the $30 \times 10 \times 3$ scheme, in which 999 thousand seedlings were planted per hectare of the experiment, in the third decade of September, September 21, 86 days after planting seedlings, 116 days after sowing seeds, they reached full ripening.

According to experimental data, the ripening period of seedlings of the mid-ripening Iskandar variety is the same as that of the early Guljahon variety, i.e. among the planted options, it was found that the variety lasted longer than 719 days, in accordance with the variety biology and planting patterns in the third decade of June $30 \times 10 \times 10$ scheme 333 thousand pcs/ha, 30x10x2 scheme 666 thousand pcs/ha, 30x10x3 scheme 999 thousand pcs/ha.

In the second decade of July (July 15), 333 thousand $\mathrm{pcs} / \mathrm{ha}$, that is, in the tenth option, planted according to the $30 \times 10 \times 1$ scheme, in the third decade of September, 101 days after planting seedlings and 131 days after sowing seeds, went into the period of full ripening. In the eleventh option, planted according to the $30 \times 10 \times 2$ pattern, with 666,000 seeds per hectare planted in the same period, in the third decade of September, September 26, 96 days after planting seedlings, 126 days after sowing seeds, the period of full ripening began. In the twelfth option of the 30x 10x3 scheme, in which 999 thousand seedlings were planted per hectare of the experiment, the third decade of September, September 23, 94 days after planting seedlings, 124 days after sowing the seeds passed the full ripening period (Table 3 ). 


\begin{tabular}{|c|c|c|c|c|c|c|c|c|c|}
\hline \multirow[b]{2}{*}{$\begin{array}{l}\text { lanting } \\
\text { cheme }\end{array}$} & \multirow{2}{*}{$\begin{array}{c}\text { Quan } \\
\text { tity of } \\
\text { seedli } \\
\text { ngs }\end{array}$} & \multirow[b]{2}{*}{$\begin{array}{l}\text { Age of } \\
\text { rice } \\
\text { seedlings }\end{array}$} & \multirow[b]{2}{*}{ Tillering } & \multirow[b]{2}{*}{$\begin{array}{c}\text { Stem } \\
\text { elongation }\end{array}$} & \multirow[b]{2}{*}{$\begin{array}{c}\text { Ear } \\
\text { formation }\end{array}$} & \multirow[b]{2}{*}{$\begin{array}{c}\text { Floweri } \\
\text { ng }\end{array}$} & \multirow[b]{2}{*}{$\begin{array}{c}\text { Ripenin } \\
\mathrm{g}\end{array}$} & \multicolumn{2}{|c|}{ Growth period } \\
\hline & & & & & & & & $\begin{array}{c}\text { Sown } \\
\text { from } \\
\text { seed }\end{array}$ & $\begin{array}{l}\text { Planted from } \\
\text { seedlings }\end{array}$ \\
\hline \multicolumn{10}{|c|}{ Guljahon variety } \\
\hline & & & 23.VII & 6.VIII & 19.VIII & 24.VIII & 23.IX & $\begin{array}{l}\text { 25.V- } \\
\text { 23.IX }\end{array}$ & 23.VII-23.IX \\
\hline \multirow[t]{2}{*}{$0 \times 10 \times 1$} & 333 & 30 & 57 & 13 & 13 & 5 & 29 & 117 & 87 \\
\hline & & & 19.VII & 2.VIII & 14.VIII & 19.VIII & 15.IX & $\begin{array}{l}25 . \mathrm{V}- \\
15 . \mathrm{IX}\end{array}$ & 19.VII-15.IX \\
\hline \multirow[t]{2}{*}{$0 \times 10 \times 2$} & 666 & 30 & 54 & 13 & 12 & 5 & 27 & 111 & 81 \\
\hline & & & 15.VII & 28.VII & 9.VIII & 14.VIII & 9.IX & $\begin{array}{c}25 . \mathrm{V}- \\
9 . \mathrm{IX}\end{array}$ & 15.VII-9.IX \\
\hline \multirow[t]{3}{*}{$0 \times 10 \times 3$} & 999 & 30 & 49 & 13 & 12 & 5 & 26 & 105 & 75 \\
\hline & \multicolumn{9}{|c|}{ Iskandar variety } \\
\hline & & & 26.VII & 8.VIII & 20.VIII & 25.VIII & 28.IX & $\begin{array}{l}\text { 25.V- } \\
\text { 28.IX }\end{array}$ & 26.VII-28.IX \\
\hline \multirow[t]{2}{*}{$0 \times 10 \times 1$} & 333 & 30 & 60 & 13 & 12 & 5 & 34 & 124 & 94 \\
\hline & & & 22.VII & 4.VIII & 16.VIII & 21.VIII & 24.IX & $\begin{array}{l}25 . V- \\
24 . I X\end{array}$ & 22.VII-24.IX \\
\hline \multirow[t]{2}{*}{$0 \times 10 x 2$} & 666 & 30 & 56 & 13 & 12 & 5 & 32 & 118 & 88 \\
\hline & & & 20.VII & 2.VIII & 14.VIII & 18.VIII & 21.IX & $\begin{array}{l}25 . \mathrm{V}- \\
21 . \mathrm{IX}\end{array}$ & 20.VII-21.IX \\
\hline \multirow[t]{2}{*}{$0 \times 10 x 3$} & 999 & 30 & 54 & 13 & 12 & 4 & 33 & 116 & 86 \\
\hline & & & 25.VII & 7.VIII & 19.VIII & 24.VIII & 27.IX & $\begin{array}{l}\text { 5.VI- } \\
\text { 27.IX }\end{array}$ & 25.VII-27.IX \\
\hline \multirow[t]{2}{*}{$0 \times 10 x 1$} & 333 & 30 & 59 & 13 & 12 & 5 & 35 & 124 & 94 \\
\hline & & & 23.VII & 6.VIII & 19.VIII & 24.VIII & 27.IX & $\begin{array}{l}\text { 5.VI- } \\
\text { 27.IX }\end{array}$ & 23.VII-27.IX \\
\hline \multirow[t]{2}{*}{$0 \times 10 \times 2$} & 666 & 30 & 57 & 14 & 13 & 5 & 34 & 123 & 93 \\
\hline & & & 19.VII & 2.VIII & 15.VIII & 20.VIII & 23.IX & $\begin{array}{l}\text { 5.VI- } \\
\text { 23.IX }\end{array}$ & 19.VII-23.IX \\
\hline \multirow[t]{2}{*}{$0 \times 10 \times 3$} & 999 & 30 & 53 & 14 & 13 & 4 & 34 & 118 & 88 \\
\hline & & & 25.VII & 8.VIII & 21.VIII & 26.VIII & 29.IX & $\begin{array}{l}\text { 15.VI- } \\
\text { 29.IX }\end{array}$ & 25.VII-29.IX \\
\hline \multirow[t]{2}{*}{$0 \times 10 x 1$} & 333 & 30 & 59 & 14 & 13 & 5 & 40 & 131 & 101 \\
\hline & & & 22.VII & 5.VIII & 18.VIII & 23.VIII & 26.IX & $\begin{array}{l}\text { 15.VI- } \\
26 . I X\end{array}$ & 22.VII-26.IX \\
\hline
\end{tabular}

\section{RESULTS}

According to the table, experiments show that two varieties of rice, early ripening "Guljahon" and mid-ripening "Iskandar" are grown in three different periods $(25.06,5.07$ and $15.07)$ and in different planting patterns (30x10x 1 , $30 \times 10 \times 2,30 \times 10 \times 3)$, from the point of view of temporal analysis, it was found that in the options with 30-day-old rice seedlings in the second decade of July, the entire vegetation period of the plant lasted 7-15 days longer than in the varieties planted in the third decade of June and the first decade of July.

Consequently, an increase in the number of rice seedlings per 1 ha leads to a reduction in the vegetative period of the plant. As a result, the nutrient area of the plant decreases, which leads to a more rapid formation of crop elements and their early maturation. In addition, water could be saved during this period when water was a problem (scarcity) and excessive water consumption was saved.

In conclusion, in the third decade of June, 333 thousand seedlings per hectare were planted according to the $30 \times 10 \times 10$ scheme, there was no significant difference between the days of 
transition to the tillering, stem elongation, ear formation and flowering stages between the Iskandar and Guljahon varieties.

The average daily temperature in the third decade of May (25.05) was $21-23{ }^{\circ} \mathrm{C}$, and the average daily temperature in the first (5.06) decade of June was $21-23{ }^{\circ} \mathrm{C}$, and the average daily temperature in the second decade of June (15.06) was $23-24^{\circ} \mathrm{C}$, it was found that the rice seeds sown during this period had a temperature of 2-3 ${ }^{\circ} \mathrm{C}$ higher, and the seeds germinated after 3-4 days, because they had already received enough heat.

Despite the fact that the Guljahon variety was sown at the same time (06/25), in the option of 333 thousand pcs/ha, 30x10x10scheme, compared with the option of 666 thousand pcs/ha,

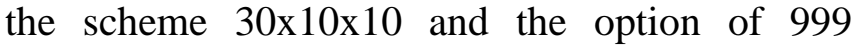
thousand $\mathrm{pcs} / \mathrm{ha}$ scheme $30 \times 10 \times 3$, it was found that the tillering period lasted 3-6 days more from the date of sowing seeds and 4-8 days from the date of sowing seedlings.

When analyzing the planting dates of Iskandar varieties, that is, seedlings planted in the third decade of June (25.06) in the first (5.07) and second decades of July (15.07) and planting patterns, it was found that the tillering period of the planting scheme $30 \times 10 \times 1$ compared to

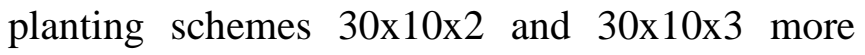
than 4-7 days.

Compared to the early-ripening Guljahon variety, the tillering period of mid-ripening Iskandar rice seedlings is the same, that is, in the third decade of June (25.06) between the options planted according to the $30 \times 10 \times 1333$ thousand $\mathrm{pcs} / \mathrm{ha}$ scheme, the $30 \times 10 \times 2666$ thousand $\mathrm{pcs} / \mathrm{ha}$ scheme, the 30x10x3 999 thousand pcs/ha scheme ha, according to the biology of the variety and planting patterns lasted more than 4-11 days.

In both varieties of the experiment, the early ripening Guljahon and mid-ripening Iskandar in the period of stem elongation amounted to 333 thousand units per hectare, i.e. in the option with planting seedlings according to the scheme $30 \times 10 \times 1$.
Both varieties of the experiment, that is, the early ripening Guljahon and mid-ripening Iskandar, yielded 333,000 per hectare during the stem elongation period, it was noted that there was no significant difference between the options planted according to the $30 \times 10 \times 2$ scheme with 66 thousand seedlings per hectare and the options according to the $30 \times 10 \times 3$ scheme planted with 999 thousand seedlings per hectare, with an average difference of almost 1-2 days.

\section{CONCLUSIONS}

In the conditions of meadow and bog soils in Andijan region, in the system of precise cultivation of rice of the Guloakhon variety recommended for rice cultivation by the method of re-planting after winter wheat, the terms, pattern, number of seedlings, total useful temperature, duration of the growing season and high productivity were specified and these acceptable values were determined in the new rice variety "Iskandar". It was determined, it is effective that, in the Guljahon variety sowing period is the third decade of June (25.06, average daily temperature $23.2{ }^{\circ} \mathrm{C}$ ), when the total useful temperature is $2171{ }^{0} \mathrm{C}$, the scheme is $30 \times 10 \times 2$ and 666 thousand seedlings per hectare, In the "Iskandar" variety, it is effective, when the sowing period is the first ten days of July (5.07, average daily temperature $28.4{ }^{0} \mathrm{C}$ ), the total useful temperature is $2322{ }^{0} \mathrm{C}$, the scheme is $30 \times 10 \times 2$ and 666 thousand seedlings per hectare. Despite the fact that the early ripening variety Guljahon was planted at the same time (June 25), it was found that the ripening period lasted 6-12 days longer, in the option sown 33 thousand pcs/ha of the 30x10x1 scheme than in the option sown 666 thousand pcs/ha scheme 30x10x2 and in the option sown 999 thousand pcs/ha scheme $30 \times 10 \times 3$. This is due to the fact that it was found that in the options of 333 thousand pcs/ha the tillering level is high, and it takes a lot of time to ripen the crop elements. As a result of the analysis of the sowing dates for Iskandar varieties, i.e. in the third decade of June (25.06), in the first (5.07) and second decade of July (15.07) and in the 
results of the analysis according to the sowing patterns, it was found that the tillering period according to the $30 \times 10 \times 1$ scheme was 4-7 days longer than the options on the $30 \times 10 \times 2$ schemes and $30 \times 10 \times 3$, and the ripening period was $6-12$ days longer, but there was no significant difference between the options during the periods of ear formation and flowering.

\section{REFERENCES}

[1] Garin. Method for determining glassiness. 2006

[2] Dospehov B.A. Methodology of field experience. Moscow: Kolos.

[3] 1985.p. 350-423

[4] Nurmatov Sh., Mirzajonov Q. et.al. Methods of conducting field experiments. Toshkent-2007. p. 8-51

[5] Ochilov E., Kashkarov N. Fundamentals of scientific research in botany Namangan. 2007. p. 3-8.
[6]

Ergashev.M.

Dissertation

on

"Determination of alternative timing of planting rice as a primary and secondary crop." 2008. p. 42-84.

[7] Ergashev. M. A. Compact, productive, perfect, «Agriculture of Uzbekistan». 2006 №2. p.20-21.

[8] Urazmetov K.K. Development of alternative timing of sowing rice as a main and secondary crop. 2014. p.23-24.

[9] Kashkabaeva Ch.T. Study of the influence of agrotechnics on the yield of mid-ripening rice varieties in meadow-swampy soil conditions. Tashkent. 2018. p. 74-109.

[10] Dar MH, Singh S, Singh US, Zaidi NW, Ismail A.M. Stress tolerant rice varietiesmaking headway in India. SATSA Mukhaptra Annual Technical Issue 18 (2014)

P.1-4

Picture 1.

Data on the degree of germination of seeds of rice varieties \% ((2017-2019) (in the laboratory)

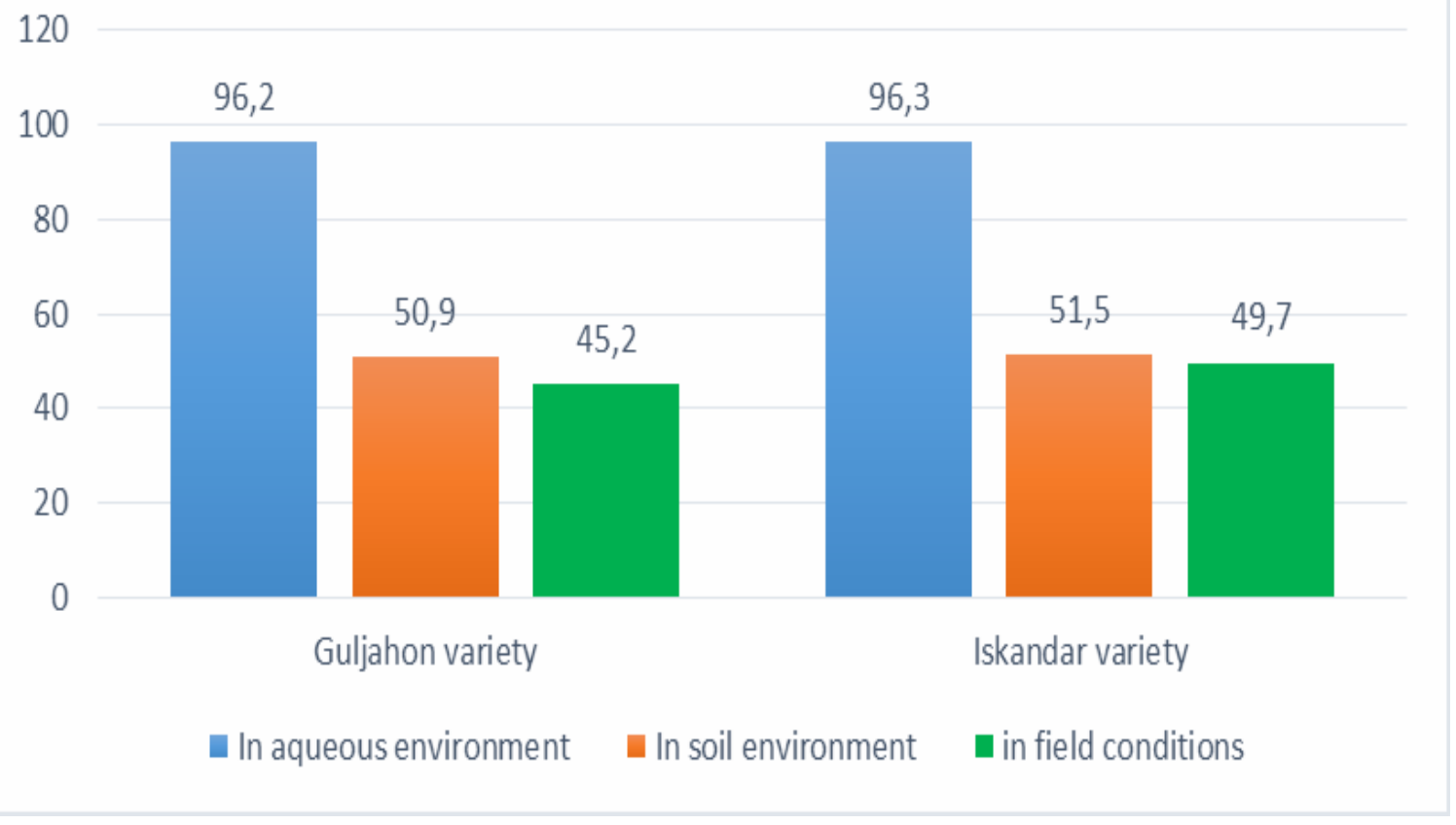

